\title{
MCM10 overexpression implicates adverse prognosis in urothelial carcinoma
}

\author{
Wei-Ming $\mathrm{Li}^{1,2,3,4}$, Chun-Nung Huang ${ }^{2,3}$, Hung-Lung $\mathrm{Ke}^{2,3}$, Ching-Chia Li ${ }^{2,3,5}$, Yu-Ching \\ Wei $^{6}$, Hsin-Chih Yeh${ }^{2,3,5}$, Lin-Li Chang ${ }^{1,7}$, Chun-Hsiung Huang ${ }^{1,2,3}$, Peir-In Liang ${ }^{8}$, \\ Bi-Wen Yeh2,3, Ti-Chun Chan ${ }^{9}$, Chien-Feng Li ${ }^{9,10,11,12,13}$, Wen-Jeng Wu1,2,3,5,14,15,16 \\ ${ }^{1}$ Graduate Institute of Medicine, College of Medicine, Kaohsiung Medical University, Kaohsiung, Taiwan \\ ${ }^{2}$ Department of Urology, Kaohsiung Medical University Hospital, Kaohsiung, Taiwan \\ ${ }^{3}$ Department of Urology, School of Medicine, College of Medicine, Kaohsiung Medical University, Kaohsiung, Taiwan \\ ${ }^{4}$ Department of Urology, Ministry of Health and Welfare Pingtung Hospital, Pingtung, Taiwan \\ ${ }^{5}$ Department of Urology, Kaohsiung Municipal Ta-Tung Hospital, Kaohsiung, Taiwan \\ ${ }^{6}$ Department of Pathology, Kaohsiung Municipal Ta-Tung Hospital, Kaohsiung, Taiwan \\ ${ }^{7}$ Department of Microbiology, School of Medicine, College of Medicine, Kaohsiung Medical University, Kaohsiung, Taiwan \\ ${ }^{8}$ Department of Pathology, Kaohsiung Medical University Hospital, Kaohsiung, Taiwan \\ ${ }^{9}$ Department of Pathology, Chi-Mei Medical Center, Tainan, Taiwan \\ ${ }^{10}$ Departments of Biotechnology, Southern Taiwan University of Science and Technology, Tainan, Taiwan \\ ${ }^{11}$ National Cancer Research Institute, National Health Research Institutes, Tainan, Taiwan \\ ${ }^{12}$ Institute of Clinical Medicine, Kaohsiung Medical University, Kaohsiung, Taiwan \\ ${ }^{13}$ Department of Internal Medicine and Cancer Center, Kaohsiung Medical University Hospital, Kaohsiung Medical University, \\ Kaohsiung, Taiwan \\ ${ }^{14}$ Center for Infectious Disease and Cancer Research, Kaohsiung Medical University, Kaohsiung, Taiwan \\ ${ }^{15}$ Center for Stem Cell Research, Kaohsiung Medical University, Kaohsiung, Taiwan \\ ${ }^{16}$ Institute of Medical Science and Technology, National Sun Yat-sen University, Kaohsiung, Taiwan \\ Correspondence to: Chien-Feng Li, email: angelo.p@yahoo.com.tw \\ Wen-Jeng Wu, email: wejewu@kmu.edu.tw
}

Keywords: urothelial carcinoma, transcriptome, MCM10, prognosis

Received: July 20, $2016 \quad$ Accepted: October 12, $2016 \quad$ Published: October 21, 2016

\section{ABSTRACT}

Urothelial carcinoma (UC) occurs in the upper urinary tract (UTUC) and the urinary bladder (UBUC). The molecular pathogenesis of UC has not been fully elucidated. Through data mining of a published transcriptome of UBUC (GSE31684), we identified Minichromosome Maintenance Complex Component 2 (MCM2) and MCM10 as the two most significantly upregulated genes in UC progression among the MCM gene family, the key factors for the initiation of DNA replication. To validate the clinical significance of MCM2 and MCM10, immunohistochemistry, evaluated by H-score, was used in a pilot study of 50 UTUC and 50 UBUC samples. Only a high expression level of MCM10 predicted worse disease-specific survival (DSS) and inferior metastasis-free survival (MeFS) for both UTUC and UBUC. Correspondingly, evaluation of MCM10 mRNA expression in 36 UTUCs and 30 UBUCs showed significantly upregulated levels in high stage UC, suggesting its role in tumor progression. Evaluation of 340 UTUC and 296 UBUC tissue samples, respectively, demonstrated that high MCM10 immunoexpression was significantly associated with advanced primary tumors, nodal status, and the presence of vascular invasion in both groups of UCs. In multivariate Cox regression analyses, adjusted for standard clinicopathological features, MCM10 overexpression was independently associated with DSS (UTUC hazard ratio $[H R]=2.401, P=0.013$; UBUC HR=4.323, $P=0.001$ ) and with MeFS (UTUC HR=3.294, $P<0.001$; UBUC 
$\mathrm{HR}=1.972, \mathrm{P}=0.015)$. In vitro, knockdown of $M C M 10$ gene significantly suppressed cell proliferation in both $\mathrm{J82}$ and TCCSUP cells. In conclusion, MCM10 overexpression was associated with unfavorable clinicopathological characteristics and independent negative prognostic effects, justifying its potential theranostic value in UC.

\section{INTRODUCTION}

Urothelial carcinoma (UC) is the most common pathological type of urinary tract cancer. Upper urinary tract urothelial carcinoma (UTUC) comprises only 5\% of all urothelial tumors in Western countries [1], but its incidence is high in Taiwan, with a ratio 3.08:6.72, UTUC to urinary bladder urothelial carcinoma (UBUC) [2]. Despite advances in surgical technique and improved understanding of UC carcinogenesis [3-7], 5-year survival rates for patients remain suboptimal $[8,9]$. Tumor stage, grade, lymph node status, lymphovascular invasion, tumor architecture, and an infiltrative growth pattern were pathological variables identified as independent prognostic factors of recurrent UC [8, 9]. However, limitations remain for these pathological characteristics to predict the outcome of patients with UC. Accordingly, additional biomarkers are needed to detect and predict outcomes for personalized treatment of UC.

Cell proliferation, a hallmark of cancer development, is required to expand populations of cells with molecular alterations $[10,11]$. Some cell proliferation markers are effective in cancer prognostication. The most commonly used markers, such as Ki-67 and proliferating cell nuclear antigen (PCNA) [12, 13], identify malignant cancer cells because their expression coincides with DNA synthesis. Nevertheless, the utility of these markers may not be ideal. Because they do not recognize cells in the G1 phase of the cell cycle- an extended stage in many proliferating cancer cells.

The minichromosome maintenance (MCM) proteins are expressed when G0 cells enter the G1 phase, before they engage in active DNA synthesis [14]. Mcm10 functions in replication licensing at origins by converting an inactive double hexamer of Mcm2-7 into two CMG (Cdc45-MCM-GINS) complexes around dsDNA near replication forks [15]. MCM proteins can be detected in abnormal precursor malignant cells before malignant transformation is completed. Previous studies have reported that MCM protein are prospective prognosis markers in prostate [16] and lung cancers [17].

With the aim of identifying members of the MCM class that are relevant for $\mathrm{UC}$, we searched for $M C M$ family expression using a published transcription profiling database in Gene Expression Omnibus (GEO). We found that MCM10 was highly expressed in advanced stage human UBUCs, suggesting a role for this protein in cancer progression. Here, we investigate the association between MCM10 expression and UC prognosis.
RESULTS

\section{$M C M 2$ and $M C M 10$ were significantly upregulated in $\mathrm{UC}$}

Several $M C M$ gene transcripts were found to be up- or downregulated in UC (Table 1 and Figure 1). Only MCM2 and MCM10 were identified as significantly upregulated, showing a $\log _{2}$ ratio $>1$ when comparing deep and non-invasive lesions. Of note, only MCM10 revealed a significant stepwise upregulation from $\mathrm{pTa}$ to pT1 and pT1 to pT2-4 ( $\log _{2}$ ratio of 0.8053 and 0.3815 , respectively). Because MCM2 and MCM10 were the two most significantly upregulated genes, we validated the significance of the elevated expression in a pilot batch of samples.

\section{MCM10 expression was significantly associated with tumor aggressiveness}

In the initial study, both MCM2 and MCM10 overexpression were significantly associated with primary tumor status in UTUC $(P=0.048$ and 0.004 , respectively) and UBUC ( $P=0.005$ and 0.004 , respectively) (Supplementary Table S1). Interestingly, both MCM2 and MCM10 overexpression predicated worse DSS for UTUC ( $P=0.0409$ and 0.0156 , respectively) and UBUC ( $P=0.0466$ and 0.0059 , respectively). However, only MCM10 predicated inferior MeFS for both UTUC and UBUC ( $\mathrm{P}=0.0178$ and 0.0115 , respectively; Figure 2 and Supplementary Table S2) and was an independent prognosticator after multivariate analysis (Supplementary Table S3)

\section{MCM10 mRNA expression increases with higher pT stages in both UTUC and UBUC}

We evaluated $M C M 10$ transcript expression in each of 35 UTUC and 30 UBUC samples. MCM10 mRNA expression was significantly upregulated in higher stage tumors in both UTUC $(\mathrm{P}=0.001)$ and UBUC $(\mathrm{P}=0.004)$ tissue, suggesting its role in cancer progression (Figure $3 \mathrm{~A}$ and 3B).

\section{Clinicopathological features of UTUC}

Table 2 shows the clinicopathological parameters of the UTUC patients. There was no gender preference. The median age at diagnosis was 68 years (range, 34 to 
Table 1: Summary of differentially expressed genes of MCM family and showed stepwise alterations during cancer progression in the transcriptome of urothelial carcinoma of urinary bladder (GSE32894)

\begin{tabular}{|c|c|c|c|c|c|c|c|c|c|}
\hline \multirow[t]{2}{*}{ Probe } & \multicolumn{2}{|c|}{$\begin{array}{l}\text { Comparing } \\
\text { T2-4 to Ta }\end{array}$} & \multicolumn{2}{|c|}{$\begin{array}{c}\text { Comparing } \\
\text { T1 to Ta }\end{array}$} & \multicolumn{2}{|c|}{$\begin{array}{l}\text { Comparing } \\
\text { T2-4 to } \mathrm{T} 1\end{array}$} & \multirow{2}{*}{$\begin{array}{c}\text { Gene } \\
\text { Symbol }\end{array}$} & \multirow{2}{*}{ Biological Process } & \multirow{2}{*}{ Molecular Function } \\
\hline & log ratio & p-value & log ratio & p-value & log ratio & p-value & & & \\
\hline ILMN_1663195 & 0.6328 & $<0.0001$ & 0.5425 & $<0.0001$ & 0.0904 & 0.2971 & MCM7 & $\begin{array}{l}\text { DNA replication, DNA } \\
\text { replication initiation, } \\
\text { cell cycle, regulation } \\
\text { of phosphorylation, } \\
\text { regulation of } \\
\text { transcription; DNA- } \\
\text { dependent, response to } \\
\text { DNA damage stimulus, } \\
\text { transcription }\end{array}$ & $\begin{array}{l}\text { ATP binding, DNA binding, } \\
\text { nucleoside-triphosphatase } \\
\text { activity, nucleotide binding, } \\
\text { protein binding }\end{array}$ \\
\hline ILMN_1681503 & 1.0003 & $<0.0001$ & 0.8447 & $<0.0001$ & 0.1556 & 0.1331 & MCM2 & $\begin{array}{l}\text { DNA replication, DNA } \\
\text { replication initiation, } \\
\text { DNA unwinding } \\
\text { during replication, } \\
\text { cell cycle, nucleosome } \\
\text { assembly, regulation } \\
\text { of transcription; } \\
\text { DNA-dependent, } \\
\text { transcription }\end{array}$ & $\begin{array}{l}\text { ATP binding, DNA binding, } \\
\text { DNA replication origin } \\
\text { binding, metal ion binding, } \\
\text { nucleotide binding, protein } \\
\text { binding, zinc ion binding }\end{array}$ \\
\hline ILMN_1704702 & 0.447 & $<0.0001$ & 0.3643 & $<0.0001$ & 0.0828 & 0.1149 & MCM7 & $\begin{array}{l}\text { DNA replication, DNA } \\
\text { replication initiation, } \\
\text { cell cycle, regulation } \\
\text { of phosphorylation, } \\
\text { regulation of } \\
\text { transcription; DNA- } \\
\text { dependent, response to } \\
\text { DNA damage stimulus, } \\
\text { transcription }\end{array}$ & $\begin{array}{l}\text { ATP binding, DNA binding, } \\
\text { nucleoside-triphosphatase } \\
\text { activity, nucleotide binding, } \\
\text { protein binding }\end{array}$ \\
\hline ILMN_1737205 & 0.5055 & $<0.0001$ & 0.446 & $<0.0001$ & 0.0595 & 0.5164 & MCM4 & $\begin{array}{l}\text { DNA replication, DNA } \\
\text { replication initiation, } \\
\text { DNA unwinding during } \\
\text { replication, regulation } \\
\text { of transcription; } \\
\text { DNA-dependent, } \\
\text { transcription }\end{array}$ & $\begin{array}{c}\text { ATP binding, DNA } \\
\text { binding, DNA helicase } \\
\text { activity, hydrolase activity, } \\
\text { nucleoside-triphosphatase } \\
\text { activity, nucleotide binding, } \\
\text { protein binding, single- } \\
\text { stranded DNA binding }\end{array}$ \\
\hline ILMN_1798581 & 0.437 & 0.0002 & 0.4273 & 0.0002 & 0.0097 & 0.9127 & MCM8 & $\begin{array}{l}\text { DNA replication, } \\
\text { cell cycle, regulation } \\
\text { of transcription; } \\
\text { DNA-dependent, } \\
\text { transcription }\end{array}$ & $\begin{array}{l}\text { ATP binding, DNA binding, } \\
\text { nucleoside-triphosphatase } \\
\text { activity, nucleotide binding }\end{array}$ \\
\hline ILMN_1798654 & 0.7221 & $<0.0001$ & 0.583 & $<.00010$ & 0.1391 & 0.1232 & МCM6 & $\begin{array}{l}\text { DNA replication, DNA } \\
\text { replication initiation, } \\
\text { DNA unwinding } \\
\text { during replication, } \\
\text { cell cycle, regulation } \\
\text { of transcription; } \\
\text { DNA-dependent, } \\
\text { transcription }\end{array}$ & $\begin{array}{l}\text { ATP binding, DNA binding, } \\
\text { DNA helicase activity, } \\
\text { identical protein binding, } \\
\text { nucleotide binding, single- } \\
\text { stranded DNA binding }\end{array}$ \\
\hline ILMN_1800654 & 0.1068 & 0.0025 & 0.1454 & 0.0001 & -0.0386 & 0.238 & MCM7 & $\begin{array}{l}\text { DNA replication, DNA } \\
\text { replication initiation, } \\
\text { cell cycle, regulation } \\
\text { of phosphorylation, } \\
\text { regulation of } \\
\text { transcription; DNA- } \\
\text { dependent, response to } \\
\text { DNA damage stimulus, } \\
\text { transcription }\end{array}$ & $\begin{array}{l}\text { ATP binding, DNA binding, } \\
\text { nucleoside-triphosphatase } \\
\text { activity, nucleotide binding, } \\
\text { protein binding }\end{array}$ \\
\hline
\end{tabular}

(Continued) 


\begin{tabular}{|c|c|c|c|c|c|c|c|c|c|}
\hline \multirow[t]{2}{*}{ Probe } & \multicolumn{2}{|c|}{$\begin{array}{l}\text { Comparing } \\
\text { T2-4 to Ta }\end{array}$} & \multicolumn{2}{|c|}{$\begin{array}{c}\text { Comparing } \\
\text { T1 to Ta }\end{array}$} & \multicolumn{2}{|c|}{$\begin{array}{l}\text { Comparing } \\
\text { T2-4 to T1 }\end{array}$} & \multirow{2}{*}{$\begin{array}{c}\text { Gene } \\
\text { Symbol }\end{array}$} & \multirow{2}{*}{ Biological Process } & \multirow[t]{2}{*}{ Molecular Function } \\
\hline & $\log$ ratio & p-value & log ratio & p-value & $\log$ ratio & p-value & & & \\
\hline ILMN_1806818 & 0.204 & 0.039 & 0.4568 & $<0.0001$ & -0.2529 & 0.0082 & $M C M 3$ & $\begin{array}{l}\text { DNA replication, DNA } \\
\text { replication initiation, } \\
\text { cell cycle, regulation } \\
\text { of transcription; } \\
\text { DNA-dependent, } \\
\text { transcription }\end{array}$ & $\begin{array}{l}\text { ATP binding, DNA binding, } \\
\text { nucleoside-triphosphatase } \\
\text { activity, nucleotide binding, } \\
\text { protein binding }\end{array}$ \\
\hline ILMN_1815169 & 0.5307 & $<0.0001$ & 0.5146 & $<0.0001$ & 0.016 & 0.8954 & $M C M 5$ & $\begin{array}{l}\text { DNA replication, DNA } \\
\text { replication initiation, } \\
\text { cell division, regulation } \\
\text { of transcription; } \\
\text { DNA-dependent, } \\
\text { transcription }\end{array}$ & $\begin{array}{c}\text { ATP binding, DNA binding, } \\
\text { nucleotide binding, protein } \\
\text { binding }\end{array}$ \\
\hline ILMN_2224143 & 0.1157 & 0.1739 & 0.2752 & 0.0009 & -0.1595 & 0.052 & $M C M 3$ & $\begin{array}{l}\text { DNA replication, DNA } \\
\text { replication initiation, } \\
\text { cell cycle, regulation } \\
\text { of transcription; } \\
\text { DNA-dependent, } \\
\text { transcription }\end{array}$ & $\begin{array}{l}\text { ATP binding, DNA binding, } \\
\text { nucleoside-triphosphatase } \\
\text { activity, nucleotide binding, } \\
\text { protein binding }\end{array}$ \\
\hline ILMN_2407124 & 0.4594 & $<0.0001$ & 0.3002 & $<0.0001$ & 0.1592 & 0.1378 & MCM8 & $\begin{array}{l}\text { DNA replication, } \\
\text { cell cycle, regulation } \\
\text { of transcription; } \\
\text { DNA-dependent, } \\
\text { transcription }\end{array}$ & $\begin{array}{l}\text { ATP binding, DNA binding, } \\
\text { nucleoside-triphosphatase } \\
\text { activity, nucleotide binding }\end{array}$ \\
\hline ILMN_2412860 & 0.4652 & $<0.0001$ & 0.4671 & $<0.0001$ & -0.0019 & 0.9842 & $M C M 4$ & $\begin{array}{l}\text { DNA replication, DNA } \\
\text { replication initiation, } \\
\text { DNA unwinding during } \\
\text { replication, regulation } \\
\text { of transcription; } \\
\text { DNA-dependent, } \\
\text { transcription }\end{array}$ & $\begin{array}{c}\text { ATP binding, DNA } \\
\text { binding, DNA helicase } \\
\text { activity, hydrolase activity, } \\
\text { nucleoside-triphosphatase } \\
\text { activity, nucleotide binding, } \\
\text { protein binding, single- } \\
\text { stranded DNA binding }\end{array}$ \\
\hline ILMN_2413898 & 1.1868 & $<0.0001$ & 0.8053 & $<0.0001$ & 0.3815 & $<0.0001$ & MCM10 & & \\
\hline ILMN_2413899 & 0.5286 & $<0.0001$ & 0.3248 & $<0.0001$ & 0.2038 & 0.0001 & MCM10 & & \\
\hline
\end{tabular}

87 years). Sixty-two (18.2\%) patients had multifocal tumors. Forty-nine (14.4\%) patients suffered from tumors involving both the renal pelvis and ureter. Most UTUCs $(n=284,83.5 \%)$ were of high tumor grade. Around half the patients $(159,46.8 \%)$ presented with muscle invasive disease. Lymph node metastasis was detected in $28(8.2 \%)$ patients.

\section{Clinicopathological features of UBUC}

As summarized in Table 2, most UBUC patients were male $(n=216,73.2 \%)$ and elderly (more than 65 years; $n=214,72.5 \%)$. Most UBUC tumors $(n=239,81 \%)$ had a high histological grade. Muscle-invasive disease was diagnosed in $123(41.7 \%)$ patients. Of these, 29 (23.6\%) patients had nodal metastases.

\section{Correlation of MCM10 expression with clinicopathological features in $\mathrm{UC}$}

Because MCM10 was identified as the most significantly upregulated gene in $M C M$ family, we further explored the significance of its expression in a large cohort of cases using immunohistochemistry. Increased MCM10 expression increased with increasing pT stage (Figure 4). In the 635 cases, MCM10 showed variable nuclear expression in both UTUC and UBUC with median H-scores of 160 (range, 100-380) and 165 (range, 100-370), respectively. After the tumors were dichotomized into those with low and high MCM10 expression (Table 2), high MCM10 was significantly associated with increased tumor stage (both UTUC and UBUCP $<0.001$ ), higher histological grade (UTUC $\mathrm{P}<0.001$; UBUC, $P=0.003$ ), lymph node metastasis (UTUC, $\mathrm{P}=0.002$; UBUC, $\mathrm{P}=0.004$ ), vascular invasion (UTUC, $\mathrm{P}<0.001$; UBUC, $\mathrm{P}=0.001$ ), perineurial invasion (UTUC, $\mathrm{P}<0.001$; $\mathrm{UBUC}, \mathrm{P}=0.021$ ) and frequent mitosis (both UTUC and UBUCP $<0.001$ ). These findings suggested a potential role of MCM10 in the progression of UCs.

\section{Patient outcome for UTUC}

Follow-up information was available for all UTUC patients for 1 to 176 months (median, 38 months). Table 3 
summarizes the association between patient outcomes and important clinicopathological parameters. Multivariate analysis revealed a number of features that predicted poor DSS, including multifocality $(\mathrm{P}=0.018)$, histological grade $(\mathrm{P}=0.020)$, lymph node metastasis $(\mathrm{P}<0.001)$, and perineurial invasion $(\mathrm{P}=0.002)$. Similar results were observed for MeFS. Vascular invasion in UTUC was also independently associated with worse MeFS $(\mathrm{P}=0.009)$. More importantly, patients with high MCM10 expression had significantly worse DSS and MeFS in both univariate $(\mathrm{P}<0.0001$, Figure 5A and 5B) and multivariate analyses $(\mathrm{P}=0.013$ and $\mathrm{P}<0.001$, respectively).

\section{Survival analysis for UBUC}

The median follow-up time was 23.1 months (range, 1 to 109 months) in UBUC patients. As shown in Table 4, pT stage and mitotic rate significantly predicted both

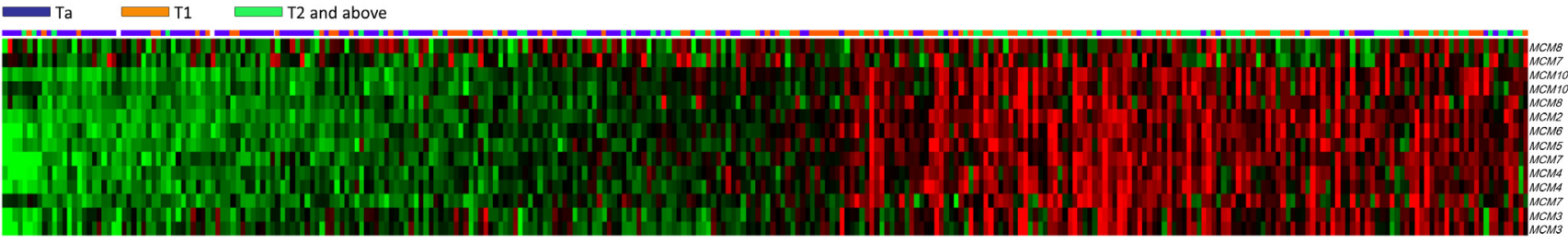

Figure 1: Analysis of transcriptome dataset in urothelial carcinoma from a published transcriptomic dataset (GSE32894). Clustering analysis of genes focusing on the $M C M$ gene family revealed that $M C M 10$ is the most significantly up-regulated gene associated with increments in the pT status, followed by $M C M 2$, prompting us to further validate their significance in our pilot batch of cases. Tissue specimens from tumors with different $\mathrm{pT}$ statuses are indicated at the top of the heatmap, and expression levels of up-regulated and down-regulated genes are represented using a brightness spectrum of red and green, respectively. Cases with unaltered mRNA transcriptional levels are coded black.
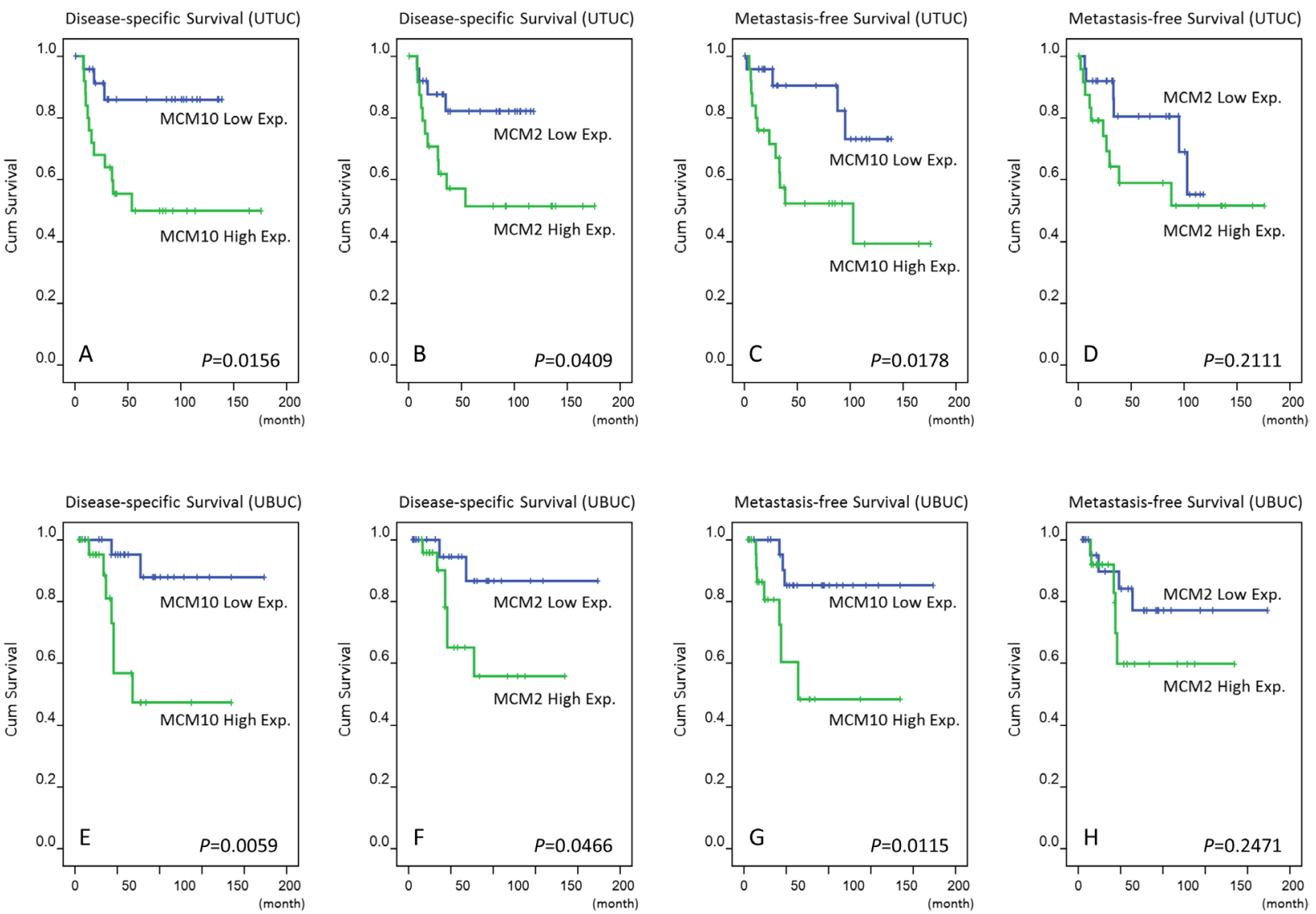

Figure 2: Validation using immunohistochemistry for our pilot batch of 50 upper urinary tract urothelial carcinomas (UTUC, A, B, C, D) and urinary bladder urothelial carcinomas (UBUC, E, F, G, H). MCM10 high expression significantly predicted inferior disease-specific survival (DSS) and metastasis-free survival (MeFS) for both UTUCs and UBUCs, while MCM2 is predictive only for DSS. 
inferior DSS $(\mathrm{P}<0.001$ and $\mathrm{P}=0.024$, respectively) and MeFS ( $P=0.015$ and $P=0.019$, respectively) in multivariate analysis. Of note, MCM10 overexpression also predicted inferior DSS and MeFS after both univariate $(\mathrm{P}<0.0001$, Figure $5 \mathrm{C}$ and $5 \mathrm{D})$ and multivariate analyses $(\mathrm{P}=0.001$ and $\mathrm{P}=0.015$, respectively).

\section{MCM10 expression promotes growth of urothelial cells in vitro}

To gain insight into the biology, we next characterized the UC cell lines for their endogenous MCM10 expression. Of the eight UC cell lines tested, the endogenous expression levels of MCM10 mRNA and protein were higher in J82 and TCCSUP cells using RT4 cells as the baseline reference (Figure 6A). We thus employed RNA interference to decipher the functional effects of MCM10 overexpression, and remarkable silencing of MCM10 expression was achieved in selected stable clones of J82 (Figure 6B, left) and TCCSUP cells (Figure 6B, right). Compared with their shLacZ controls, the BrdU incorporation rates in both stable MCM10silenced J82 and TCCSUP cells were significantly attenuated (Figure 6C). This finding indicated the growthpromoting role of MCM10.

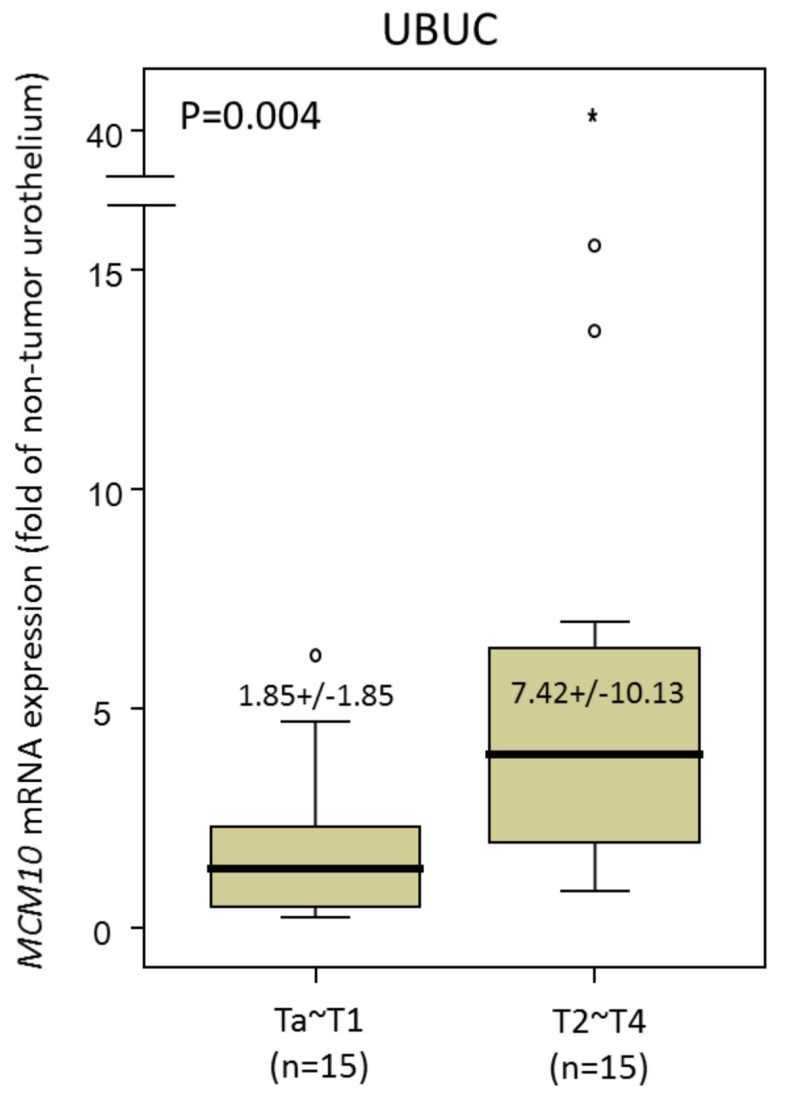

\section{DISCUSSION}

Currently, few effective biomarkers for early prognostication of UC exist. In this study, we identified a molecule that could provide additional information for designing further treatment plans and that goes beyond traditional TNM staging or tumor grade. Because cell proliferation is a hallmark of cancer $[10,11]$, we focused on MCM genes, key factors for initiation of DNA replication. Through data mining, we identified two potential prognosticators, MCM2 and MCM10, and performed a pilot study to validate the role of these genes in UC. Only MCM10 overexpression significantly predicted worse DSS and inferior MeFS for both UTUC and UBUC. We further confirmed the clinical significance of MCM10 expression in well-characterized cohorts of 340UTUCs and 296 UBUCs. We demonstrated that MCM10 immunoexpression was significantly associated with aggressive pathological features, including advanced primary tumor status, vascular invasion, and nodal metastasis in both groups of UCs. MCM10 overexpression was independently associated with MeFS and DSS. These findings indicate that standard clinicopathological practice could benefit by adding MCM10 status to improve risk stratification for UC.

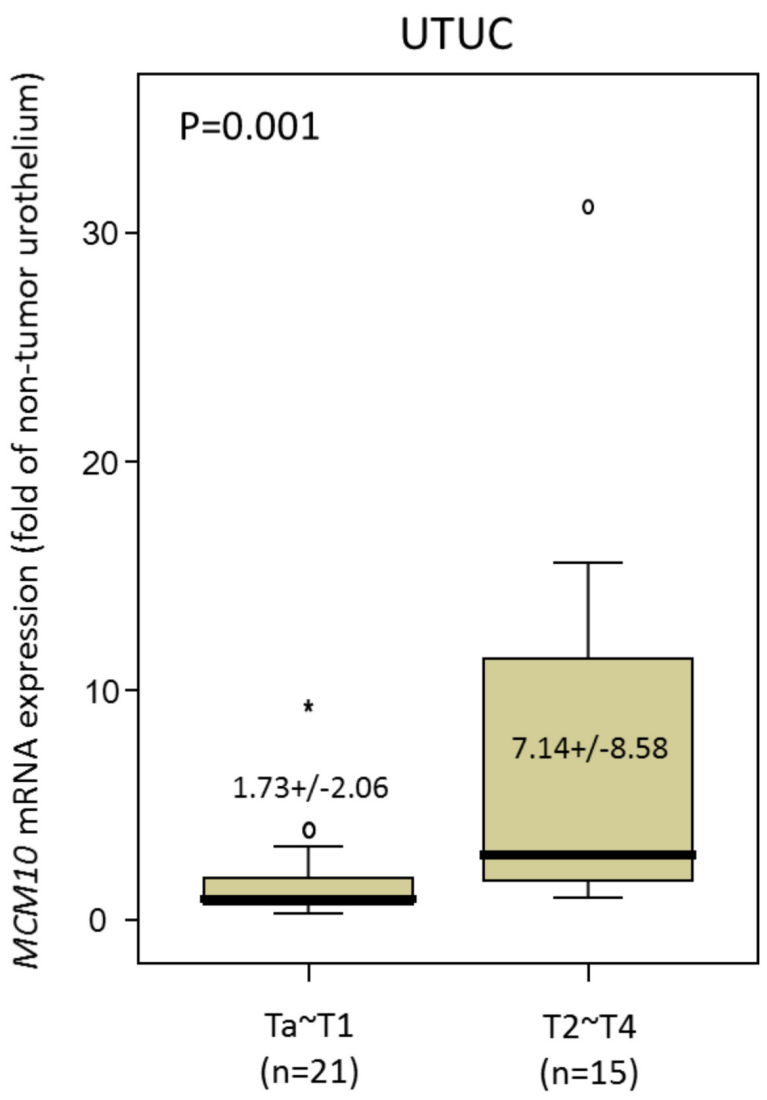

Figure 3: QuantiGene assay. MCM10 mRNA expression was significantly increased in both UBUCs (left panel) and UTUCs (right panel) with advanced primary $\mathrm{pT}$ status. ( $\mathrm{p}=0.004$ and $\mathrm{p}=0.001$, respectively). 
Table 2: Correlations between MCM10 expression and other important clinicopathological parameters in urothelial carcinomas

\begin{tabular}{|c|c|c|c|c|c|c|c|c|c|}
\hline \multirow{3}{*}{ Parameter } & \multirow{3}{*}{ Category } & \multicolumn{4}{|c|}{ Upper Urinary Tract Urothelial Carcinoma } & \multicolumn{4}{|c|}{ Urinary Bladder Urothelial Carcinoma } \\
\hline & & \multirow{2}{*}{ Case No. } & \multicolumn{2}{|c|}{ MCM10 Expression } & \multirow{2}{*}{ p-value } & \multirow{2}{*}{ Case No. } & \multicolumn{2}{|c|}{ MCM10 Expression } & \multirow{2}{*}{ p-value } \\
\hline & & & Low & High & & & Low & High & \\
\hline \multirow[t]{2}{*}{ Gender } & Male & 158 & 85 & 73 & 0.192 & 216 & 111 & 105 & 0.376 \\
\hline & Female & 182 & 95 & 97 & & 79 & 36 & 43 & \\
\hline \multirow[t]{2}{*}{ Age (years) } & $<65$ & 138 & 68 & 70 & 0.825 & 121 & 65 & 56 & 0.265 \\
\hline & $\geq 65$ & 202 & 102 & 100 & & 174 & 82 & 92 & \\
\hline \multirow[t]{3}{*}{$\begin{array}{l}\text { Tumor } \\
\text { location }\end{array}$} & Renal pelvis & 141 & 69 & 72 & 0.909 & - & - & - & - \\
\hline & Ureter & 150 & 77 & 73 & & - & - & - & - \\
\hline & $\begin{array}{l}\text { Renal pelvis } \\
\& \text { ureter }\end{array}$ & 49 & 24 & 25 & & - & - & - & - \\
\hline \multirow[t]{2}{*}{ Multifocality } & Single & 278 & 141 & 137 & 0.574 & - & - & - & - \\
\hline & Multifocal & 62 & 29 & 33 & & - & - & - & - \\
\hline \multirow[t]{3}{*}{$\begin{array}{l}\text { Primary } \\
\text { tumor }(\mathrm{T})\end{array}$} & $\mathrm{Ta}$ & 89 & 57 & 32 & $<0.001 *$ & 84 & 52 & 32 & $<0.001 *$ \\
\hline & $\mathrm{T} 1$ & 92 & 58 & 34 & & 88 & 53 & 35 & \\
\hline & $\mathrm{T} 2-\mathrm{T} 4$ & 159 & 55 & 104 & & 123 & 42 & 81 & \\
\hline \multirow[t]{2}{*}{$\begin{array}{l}\text { Nodal } \\
\text { metastasis }\end{array}$} & $\begin{array}{l}\text { Negative } \\
\text { (N0) }\end{array}$ & 312 & 164 & 148 & $0.002 *$ & 266 & 140 & 126 & $0.004 *$ \\
\hline & $\begin{array}{l}\text { Positive (N1- } \\
\text { N2) }\end{array}$ & 28 & 6 & 22 & & 29 & 7 & 22 & \\
\hline \multirow[t]{2}{*}{$\begin{array}{l}\text { Histological } \\
\text { grade }\end{array}$} & Low grade & 56 & 42 & 14 & $<0.001 *$ & 56 & 38 & 18 & $0.003 *$ \\
\hline & High grade & 284 & 128 & 156 & & 239 & 109 & 130 & \\
\hline \multirow[t]{2}{*}{$\begin{array}{l}\text { Vascular } \\
\text { invasion }\end{array}$} & Absent & 234 & 140 & 94 & $<0.001 *$ & 246 & 133 & 113 & $0.001 *$ \\
\hline & Present & 106 & 30 & 76 & & 49 & 14 & 35 & \\
\hline \multirow[t]{2}{*}{$\begin{array}{l}\text { Perineural } \\
\text { invasion }\end{array}$} & Absent & 321 & 168 & 153 & $<0.001 *$ & 275 & 142 & 133 & $0.021 *$ \\
\hline & Present & 19 & 2 & 17 & & 20 & 5 & 15 & \\
\hline \multirow{2}{*}{$\begin{array}{l}\text { Mitotic rate } \\
\text { (per } 10 \text { high } \\
\text { power fields) }\end{array}$} & $<10$ & 173 & 125 & 48 & $<0.001 *$ & 139 & 85 & 54 & $<0.001 *$ \\
\hline & $>=10$ & 167 & 45 & 122 & & 156 & 62 & 94 & \\
\hline
\end{tabular}

* Statistically significant.

MCM2-7, a complex of six subunits, is an essential component of the prereplication chromatin assembled at the replication origins during the G1 phase and with the processive helicase at growing forks. In the G1 phase of the cell cycle, Cdc6, Cdt1, and Mcm2-7 are recruited to the replication origins in an origin recognition complexdependent process to form a prereplicative complex (pre-RC) [18]. Upon entry into S phase, the conversion of pre-RCs into active replication forks initiates DNA replication. This transformation requires the activity of two families of protein kinases, the $\mathrm{Cdc} 7 / \mathrm{Dbf} 4$ kinases and the S phase cyclin-dependent kinases (Cdks) [19]. The loaded complex is then activated in situ during the S-phase by recruitment of Cdc45 protein and the GINS complex to form the active Cdc45-MCM-GINS (CMG) helicase, which has a variety of regulatory factors assembled around 
it at nascent DNA replication forks [20]. Subsequently, the formation of the replisome progression complex acts as a eukaryotic replisome. As part of the protein machinery for replication licensing, the MCM complex is necessary for a quiescent cell to re-enter the cell cycle, and its components are even before DNA synthesis or cancerassociated histological changes. Therefore, it might be a good marker for early detection of malignant changes at the cellular level.

The diagnostic value of MCM proteins was first verified when antibodies against MCM5 andKi-67 were compared in cervical squamous intraepithelial lesions [21]. In addition, elevated MCM2 expression in the high growth fraction of B-cell lymphomas has been reported [22]. MCM2 is also a target gene of miR-31 in suppressing medulloblastoma cell growth [23]. Furthermore, poor patient survival corresponds with increased expression of MCM2 in prostate [24], lung [25] and breast [26] cancer cells. Together these studies suggest that MCM proteins are sensitive and versatile diagnostic markers for early cancer detection and may be promising prognostic markers.

Mcm10, chromatin-associated protein, is a replication initiation protein that physically interacts with members of the MCM2-7 complex [27]. Mcm10 is an evolutionally conserved essential protein that facilitates the phosphorylation of $\mathrm{Mcm}$ complex to initiate replication [28]. MCM10 is important for efficient DNA replication origin firing in human cells [29]; it also promotes origin unwinding, and promotes the recruitment of both replication protein A (RPA) and DNA polymerases to the origin [30].

In previous studies, defects in the loading or activation of the Mcm2-7 complex in budding yeast impeded checkpoint activation [31]. One study found that checkpoint activation was defective following the depletion of Mcm10 [32]. A different study reported that there might be an interaction between BRCA2 and MCM10, which may serve as a checkpoint, and may be important for stabilizing the replication fork [33]. Loss of these functions results in severe defects in DNA doublestrand break repair and may lead to tumorgenesis. Such findings imply that MCM10 could be important for repair of defective genes. However, most studies show its association with malignant behavior of cancer cells.

We found a significant association between MCM10 expression and pT stage. Other parameters,
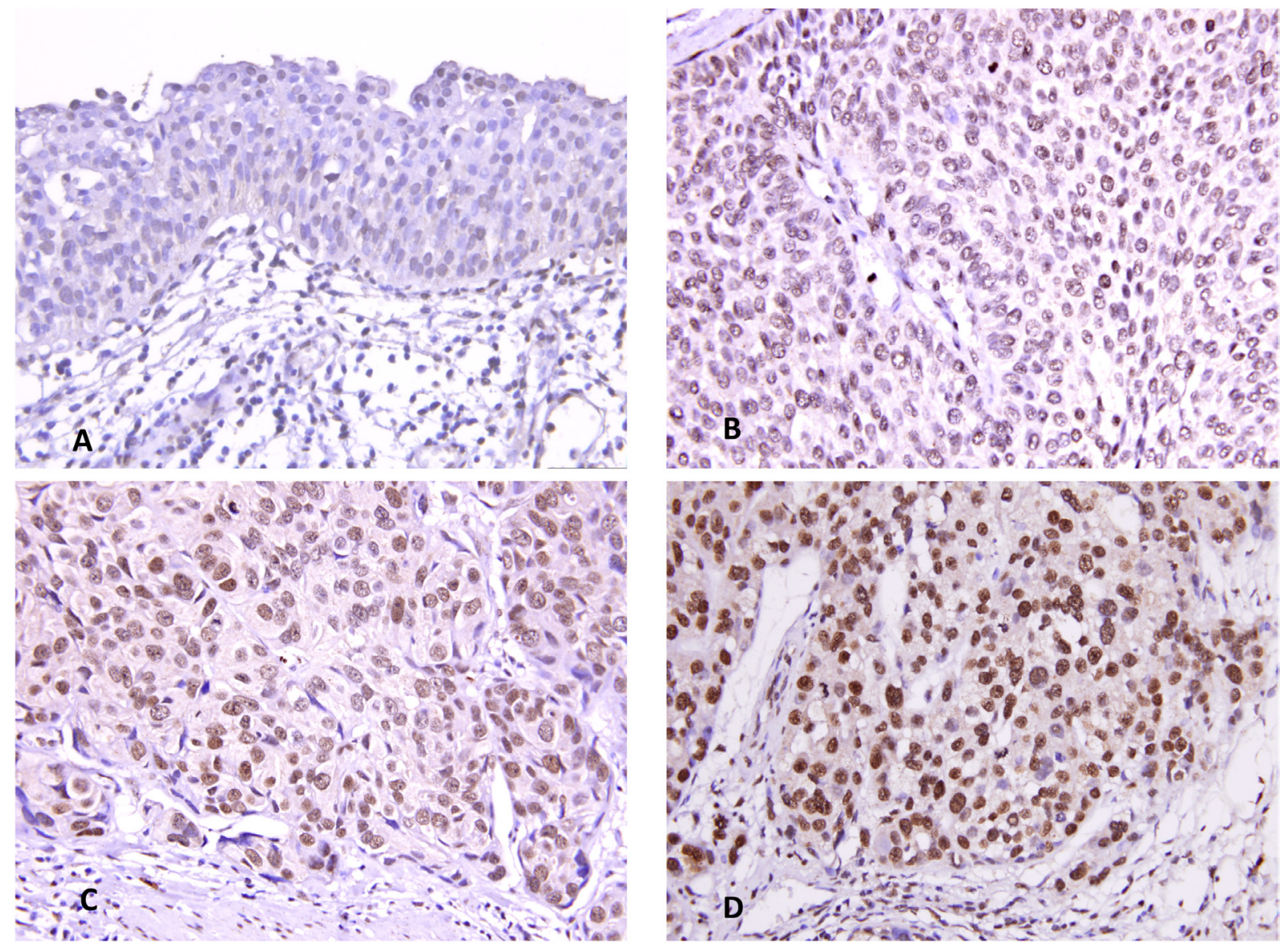

Figure 4: MCM10 immunostaining. Representative sections of non-tumor urothelium A., non-invasive urothelial carcinoma B., superficially invasive urothelial carcinoma C., and high-stage infiltrating urothelial carcinoma D. exhibit a stepwise increment. 
Table 3: Univariate log-rank and multivariate analyses for Disease-specific and Metastasis-free Survivals in Upper urinary tract urothelial carcinoma

\begin{tabular}{|c|c|c|c|c|c|c|c|c|c|c|c|c|}
\hline \multirow{3}{*}{ Parameter } & \multirow{3}{*}{ Category } & \multirow{3}{*}{ Case No. } & \multicolumn{5}{|c|}{ Disease-specific Survival } & \multicolumn{5}{|c|}{ Metastasis-free Survival } \\
\hline & & & \multicolumn{2}{|c|}{ Univariate analysis } & \multicolumn{3}{|c|}{ Multivariate analysis } & \multicolumn{2}{|c|}{ Univariate analysis } & \multicolumn{3}{|c|}{ Multivariate analysis } \\
\hline & & & No. of event & p-value & R.R. & 95\% C.I. & p-value & No. of event & p-value & R.R. & 95\% C.I. & p-value \\
\hline \multirow[t]{2}{*}{ Gender } & Male & 158 & 28 & 0.8286 & - & - & - & 32 & 0.7904 & - & - & - \\
\hline & Female & 182 & 33 & & - & - & - & 38 & & - & - & - \\
\hline \multirow[t]{2}{*}{ Age (years) } & $<65$ & 138 & 26 & 0.9943 & - & - & - & 30 & 0.8470 & - & - & - \\
\hline & $\geq 65$ & 202 & 35 & & - & - & - & 40 & & - & - & - \\
\hline \multirow[t]{3}{*}{ Tumor side } & Right & 177 & 34 & 0.7366 & - & - & - & 38 & 0.3074 & - & - & - \\
\hline & Left & 154 & 26 & & - & - & - & 32 & & - & - & - \\
\hline & Bilateral & 9 & 1 & & - & - & - & 0 & & - & - & - \\
\hline \multirow[t]{3}{*}{$\begin{array}{l}\text { Tumor } \\
\text { location }\end{array}$} & Renal pelvis & 141 & 24 & $0.0079 *$ & 1 & - & 0.706 & 31 & 0.0659 & - & - & - \\
\hline & Ureter & 150 & 22 & & 0.820 & $\begin{array}{c}0.440- \\
1.526\end{array}$ & & 25 & & - & - & - \\
\hline & $\begin{array}{l}\text { Renal pelvis } \\
\& \text { ureter }\end{array}$ & 49 & 15 & & 1.361 & $\begin{array}{c}0.377- \\
4.913\end{array}$ & & 14 & & - & - & - \\
\hline \multirow[t]{2}{*}{ Multifocality } & Single & 273 & 48 & $0.0026^{*}$ & 1 & - & $0.018^{*}$ & 52 & $0.0127 *$ & 1 & - & $0.007 *$ \\
\hline & Multifocal & 62 & 18 & & 2.530 & $\begin{array}{l}1.173- \\
5.455\end{array}$ & & 18 & & 2.127 & $\begin{array}{l}1.224- \\
3.697\end{array}$ & \\
\hline \multirow[t]{3}{*}{$\begin{array}{l}\text { Primary } \\
\text { tumor }(T)\end{array}$} & $\mathrm{Ta}$ & 89 & 2 & $<0.0001^{*}$ & 1 & - & 0.063 & 4 & $<0.0001 *$ & 1 & - & 0.189 \\
\hline & $\mathrm{T} 1$ & 92 & 9 & & 3.337 & $\begin{array}{l}0.708- \\
15.718\end{array}$ & & 15 & & 2.792 & $\begin{array}{l}0.901- \\
8.650\end{array}$ & \\
\hline & $\mathrm{T} 2-\mathrm{T} 4$ & 159 & 50 & & 5.546 & $\begin{array}{l}1.231- \\
24.979\end{array}$ & & 51 & & 2.684 & $\begin{array}{l}0.853- \\
8.440\end{array}$ & \\
\hline \multirow[t]{2}{*}{$\begin{array}{l}\text { Nodal } \\
\text { metastasis }\end{array}$} & $\begin{array}{l}\text { Negative } \\
\text { (N0) }\end{array}$ & 312 & 42 & $<0.0001^{*}$ & 1 & - & $<0.001 *$ & 55 & $<0.0001^{*}$ & 1 & - & $0.001 *$ \\
\hline & $\begin{array}{l}\text { Positive } \\
\text { (N1-N2) }\end{array}$ & 28 & 19 & & 5.077 & $\begin{array}{c}2.740- \\
9.450\end{array}$ & & 15 & & 2.962 & $\begin{array}{l}1.603- \\
5.472\end{array}$ & \\
\hline \multirow[t]{2}{*}{$\begin{array}{l}\text { Histological } \\
\text { grade }\end{array}$} & Low grade & 56 & 4 & $0.0215^{*}$ & 1 & - & $0.020 *$ & 3 & $0.0027^{*}$ & 1 & - & $0.014 *$ \\
\hline & High grade & 284 & 57 & & 3.729 & $\begin{array}{l}1.234- \\
11.272\end{array}$ & & 67 & & 4.550 & $\begin{array}{l}1.351- \\
15.301\end{array}$ & \\
\hline \multirow[t]{2}{*}{$\begin{array}{l}\text { Vascular } \\
\text { invasion }\end{array}$} & Absent & 234 & 24 & $<0.0001^{*}$ & 1 & - & 0.130 & 26 & $<0.0001 *$ & 1 & - & $0.009^{*}$ \\
\hline & Present & 106 & 37 & & 1.579 & $\begin{array}{l}0.874- \\
2.853\end{array}$ & & 44 & & 2.226 & $\begin{array}{l}1.223- \\
4.053\end{array}$ & \\
\hline \multirow[t]{2}{*}{$\begin{array}{l}\text { Perineural } \\
\text { invasion }\end{array}$} & Absent & 321 & 50 & $<0.0001^{*}$ & 1 & - & $0.002 *$ & 61 & $<0.0001 *$ & 1 & - & $0.041^{*}$ \\
\hline & Present & 19 & 11 & & 3.248 & $\begin{array}{l}1.537- \\
6.864\end{array}$ & & 9 & & 2.181 & $\begin{array}{l}1.032- \\
4.609\end{array}$ & \\
\hline \multirow{2}{*}{$\begin{array}{l}\text { Mitotic rate } \\
\text { (per } 10 \text { high } \\
\text { power fields) }\end{array}$} & $<10$ & 173 & 27 & 0.167 & - & - & - & 30 & 0.0823 & - & - & - \\
\hline & $>=10$ & 167 & 34 & & - & - & - & 40 & & - & - & - \\
\hline \multirow[t]{2}{*}{$\begin{array}{l}\text { MCM10 } \\
\text { expression }\end{array}$} & Low & 170 & 12 & $<0.0001^{*}$ & 1 & - & $0.013^{*}$ & 13 & $<0.0001 *$ & 1 & - & $<0.001 *$ \\
\hline & High & 170 & 49 & & 2.401 & $\begin{array}{l}1.201- \\
4.800\end{array}$ & & 57 & & 3.294 & $\begin{array}{l}1.704- \\
6.367\end{array}$ & \\
\hline
\end{tabular}

* Statistically significant. 
such as node metastasis, tumor grade, and perineurial invasion were significant prognostic factors in UTUC, even in multivariate analysis. However, the only significant prognosticator in UBUC was increasing MCM10 expression. The more invasive the UC, whether UTUC or UBUC, the higher the MCM10 expression.
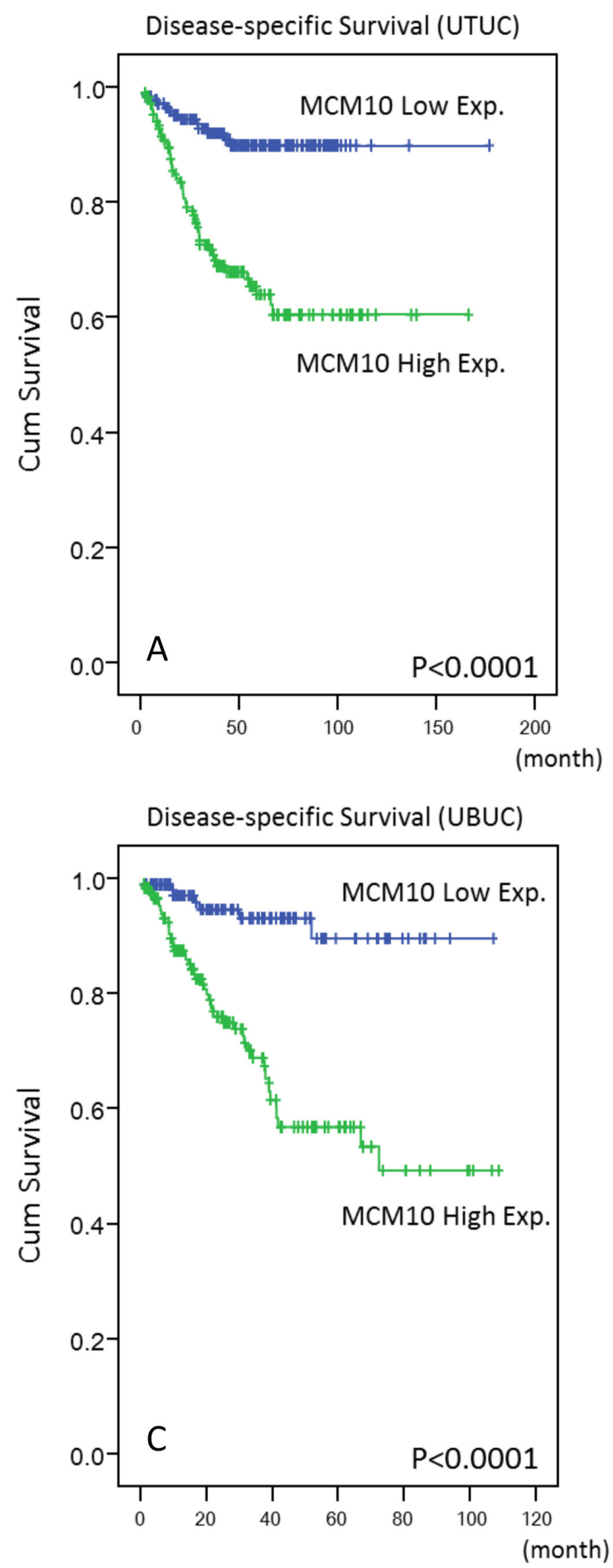

This is consistent with the idea that more cell cycle activation relates to increased proliferation in cancer cells. In addition, we also found that higher expression of MCM10corresponded with worse outcomes of cancerspecific survival and metastasis risk in both types of UC. Our results provide the first data suggesting that MCM10
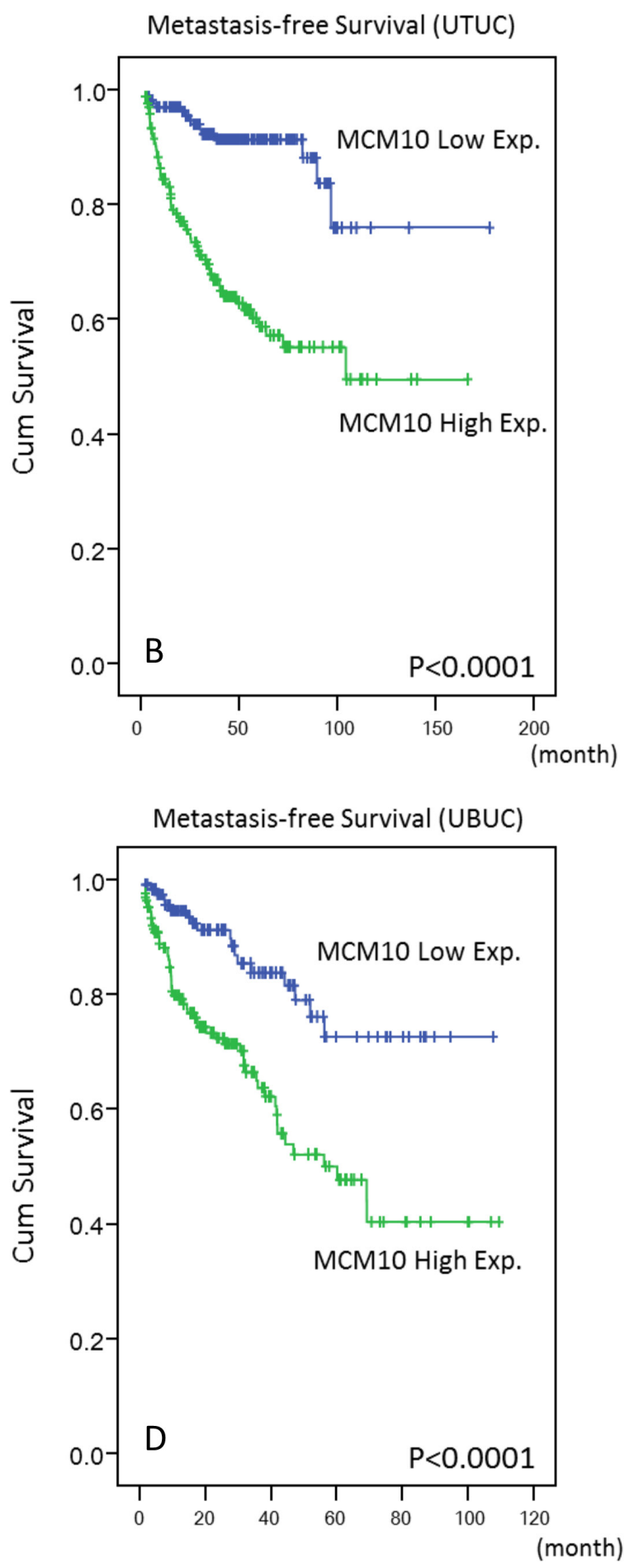

Figure 5: Kaplan-Meier plots. These plots show the prognostic significance of MCM10 expression for DSS and MeFS of UTUC A \& B. and UBUC C \& D. 
Table 4: Univariate log-rank and multivariate analyses for Disease-specific and Metastasis-free Survivals in urinary bladder urothelial carcinoma

\begin{tabular}{|c|c|c|c|c|c|c|c|c|c|c|c|c|}
\hline \multirow{3}{*}{ Parameter } & \multirow{3}{*}{ Category } & \multirow{3}{*}{ Case No. } & \multicolumn{5}{|c|}{ Disease-specific Survival } & \multicolumn{5}{|c|}{ Metastasis-free Survival } \\
\hline & & & \multicolumn{2}{|c|}{ Univariate analysis } & \multicolumn{3}{|c|}{ Multivariate analysis } & \multicolumn{2}{|c|}{ Univariate analysis } & \multicolumn{3}{|c|}{ Multivariate analysis } \\
\hline & & & No. of event & p-value & R.R. & 95\% C.I. & p-value & $\begin{array}{l}\text { No. of } \\
\text { event }\end{array}$ & p-value & R.R. & 95\% C.I. & p-value \\
\hline \multirow[t]{2}{*}{ Gender } & Male & 216 & 41 & 0.4446 & - & - & - & 60 & 0.2720 & - & - & - \\
\hline & Female & 79 & 11 & & - & - & - & 16 & & - & - & - \\
\hline \multirow[t]{2}{*}{ Age (years) } & $<65$ & 121 & 17 & 0.1136 & - & - & - & 31 & 0.6875 & - & - & - \\
\hline & $\geq 65$ & 174 & 35 & & - & - & - & 45 & & - & - & - \\
\hline \multirow[t]{3}{*}{$\begin{array}{l}\text { Primary } \\
\text { tumor }(T)\end{array}$} & $\mathrm{Ta}$ & 84 & 1 & $<0.0001^{*}$ & 1 & - & $<0.001 *$ & 4 & $<0.0001 *$ & 1 & - & $0.015^{*}$ \\
\hline & $\mathrm{T} 1$ & 88 & 9 & & 7.441 & $\begin{array}{l}0.790- \\
70.108\end{array}$ & & 23 & & 5.546 & $1.597-19.252$ & \\
\hline & $\mathrm{T} 2-\mathrm{T} 4$ & 123 & 42 & & 29.581 & $\begin{array}{c}3.184- \\
274.822\end{array}$ & & 49 & & 8.230 & $2.352-28.798$ & \\
\hline \multirow[t]{2}{*}{$\begin{array}{l}\text { Nodal } \\
\text { metastasis }\end{array}$} & $\begin{array}{l}\text { Negative } \\
\text { (N0) }\end{array}$ & 266 & 41 & $0.0002 *$ & 1 & - & 0.761 & 61 & $<0.0001 \%$ & 1 & - & 0.100 \\
\hline & $\begin{array}{l}\text { Positive } \\
\text { (N1-N2) }\end{array}$ & 29 & 11 & & 1.114 & $0.554-2.239$ & & 15 & & 1.670 & $0.906-3.097$ & \\
\hline \multirow[t]{2}{*}{$\begin{array}{l}\text { Histological } \\
\text { grade }\end{array}$} & Low grade & 56 & 2 & $0.0013 *$ & 1 & - & 0.639 & 5 & $0.0007^{*}$ & 1 & - & 0.938 \\
\hline & High grade & 239 & 50 & & 0.684 & $0.140-3.345$ & & 71 & & 1.043 & $0.362-3.002$ & \\
\hline \multirow[t]{2}{*}{$\begin{array}{l}\text { Vascular } \\
\text { invasion }\end{array}$} & Absent & 246 & 37 & $0.0024^{*}$ & 1 & - & 0.135 & 54 & $0.0001^{*}$ & 1 & - & 0.812 \\
\hline & Present & 49 & 15 & & 0.585 & $0.289-1.182$ & & 22 & & 0.930 & $0.511-1.692$ & \\
\hline \multirow[t]{2}{*}{$\begin{array}{l}\text { Perineural } \\
\text { invasion }\end{array}$} & Absent & 275 & 44 & $0.0001 *$ & 1 & - & 0.066 & 66 & $0.0007 *$ & 1 & - & 0.206 \\
\hline & Present & 20 & 8 & & 2.233 & $0.947-5.262$ & & 10 & & 1.625 & $0.766-3.450$ & \\
\hline \multirow{2}{*}{$\begin{array}{l}\text { Mitotic } \\
\text { rate (per } 10 \\
\text { high power } \\
\text { fields) }\end{array}$} & $<10$ & 139 & 12 & $<0.0001 *$ & 1 & - & $0.024 *$ & 23 & $<0.0001 *$ & 1 & - & $0.019 *$ \\
\hline & $>=10$ & 156 & 40 & & 2.145 & $1.104-4.170$ & & 53 & & 1.843 & $1.105-3.075$ & \\
\hline \multirow[t]{2}{*}{$\begin{array}{l}\text { MCM10 } \\
\text { expression }\end{array}$} & Low & 147 & 10 & $<0.0001^{*}$ & 1 & - & $0.001 *$ & 23 & $<0.0001^{*}$ & 1 & - & $0.015^{*}$ \\
\hline & High & 148 & 42 & & 4.323 & $\begin{array}{c}1.797- \\
10.399\end{array}$ & & 53 & & 1.972 & $1.139-3.416$ & \\
\hline
\end{tabular}

* Statistically significant.

expression could provide an early warning for poor outcomes in UC, as it is expressed before histological changes are observable and may indicate the need of a more aggressive treatment plan.

MCM10 is a turnkey of the MCM complex in cancer proliferation, making it a strong target for anticancer therapy. In general, it has been suggested that anti-MCM molecules are potential therapeutics for cancer [34]. To date, several studies have reported that antiMCM small molecules are potentially effective against a broad spectrum of cancers. Kwon et al. explored the ability of widdrol, which down-regulates MCM proteins, to inhibit growth of human colon adenocarcinoma HT29 cells in vitro [35]. Mechanistically, anti-MCM small molecules are most likely to stop the proliferation of cancer cells by blocking replication licensing or inhibiting DNA synthesis; however, recent studies showed that they could also induce apoptosis, specifically in cancer cells $[36,37]$. We have identified MCM10 as a marker of urothelial carcinoma progression with prognostic value for both upper and lower urinary tract cancers. Our findings suggest that targeting MCM10 in UC could be an effective treatment strategy that warrants future attention. 


\section{MATERIALS AND METHODS}

\section{Data mining of GEO to identify altered $M C M$ transcripts in $\mathrm{UC}$}

We performed data mining using GEO (National Center Biotechnology information, Bethesda, MD, USA) and identified one dataset, GSE32894 (http://www.ncbi. nlm.nih.gov/geo/query/acc.cgi?acc=GSE32894), which profiled radical cystectomy specimens from 308 UBUC using an Illumina HT12.0 Array. To analyze the gene expression level, we imported the raw files into the Nexus Expression 3 statistical software (BioDiscovery, EI Segundo, CA, USA). All probe sets were used in the analysis without preselection or filtering. We performed supervised comparative analysis to examine the statistical significance of differentially expressed genes based on primary tumor status (pT) progression. Therefore, we compared differential expression between muscle-invasive, high-stage (pT2-pT4), superficially invasive (pT1), and non-invasive (pTa) UCs to obtain functional profiles focused on MCM proteins. Only genes showing significant differential expression $\left(\log _{2}\right.$ ratio $>+/-0.1, p<0.01)$ were enrolled for initial validation.

\section{Patients and tumor specimens}

The institutional review board (IRB) of the Chi Mei Medical Center (CMMC) approved this study (IRB10302015). We retrieved UC cases from the BioBank of CMMC archives between 1996 and 2004 for immunohistochemical study and survival analysis. For the initial validation, aiming to identify the most significant among the candidate genes, a pilot batch of 50 UBUCs and 50UTUCs were randomly selected. The gene showing the most clinical significance was further evaluated in an independent cohort as previously described [38-40]

\section{Immunohistochemical staining}

As described previously [41, 42], tissue sections of $4-\mu \mathrm{m}$ thickness were cut onto precoated slides from paraffin-embedded tissue blocks, followed by deparaffinization, rehydration, antigen retrieval, and blockage of endogenous peroxidase. The slides were subsequently incubated with a primary antibody targeting one of two significant candidate genes, MCM2 (1:100, N-19, Santa Cruz) or MCM10 (1:150, H-41, Santa Cruz), for one hour. We used the DAKO ChemMate EnVision Kit (K5001, Carpinteria, CA, USA) to detect primary
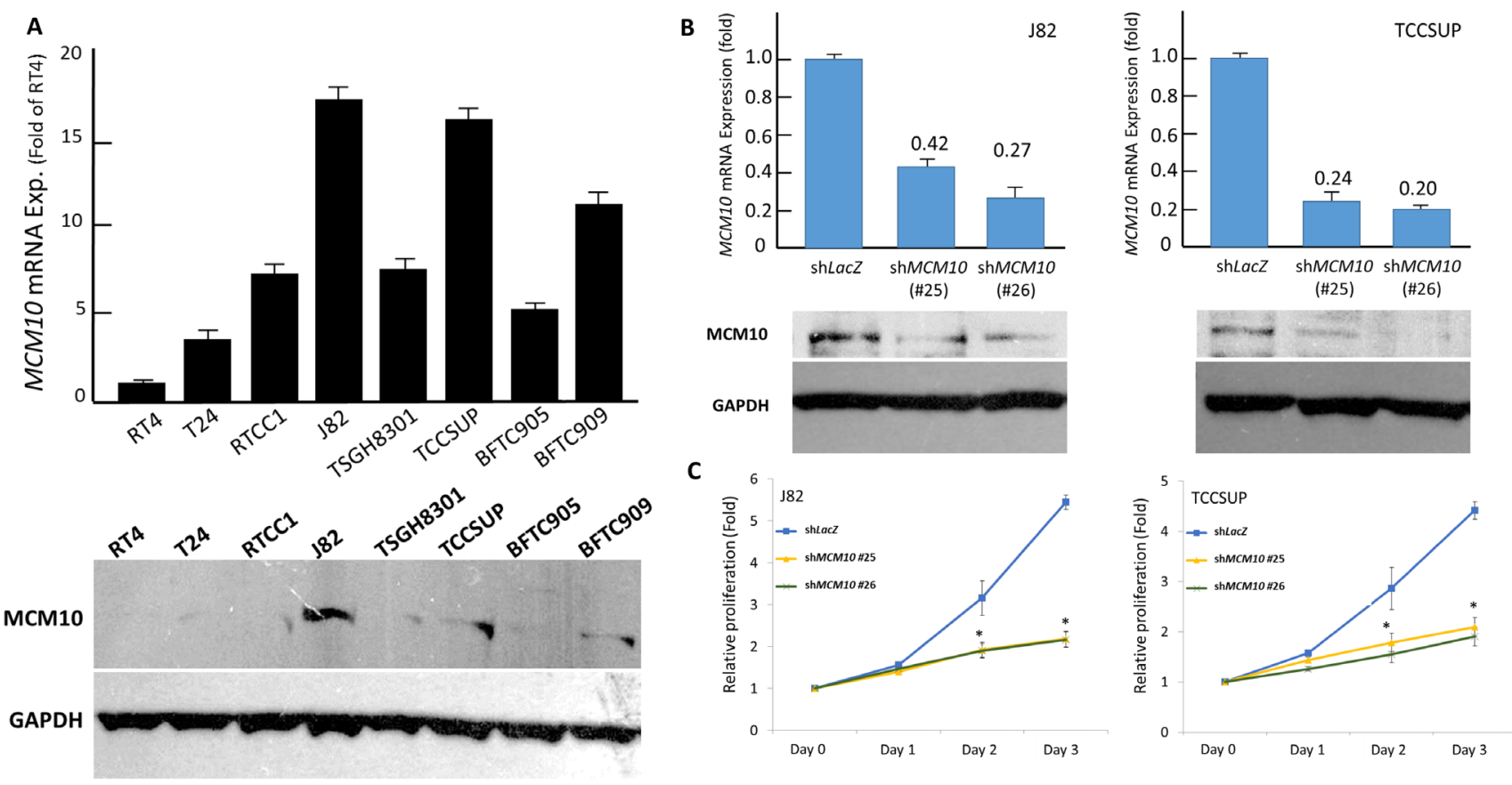

Figure 6: MCM10 expression promotes growth of UC cells in vitro. A. Compared to RT4 cells, endogenous $M C M 10 \mathrm{mRNA}$ (upper) and protein (lower) expression is higher in J82 and TCCSUP cell lines. B. The two cell lines with high endogenous MCM10 expression are stably silenced against MCM10 expression by a lentiviral vector bearing one of the two clones of MCM10 shRNA with different sequences for both J82 (left panel) and TCCSUP (right panel) cells. The efficiency of RNA silencing is confirmed by both quantitative RT-PCR (upper row) and western blotting (lower row) assays. The shLacZ plasmid, POLR2A transcript, and GADPH protein are utilized as controls in RNA interference, quantitative RT-PCR, and western blotting assays, respectively. C. Using an ELISA-based, colorimetric assay to assess the rate of BrdU uptake, cell proliferation is significantly reduced in stable MCM10-knockdown J82 (left) and TCCSUP (right) cell lines, compared to the corresponding shLacZ controls. $\left({ }^{*}, P<0.05\right)$. 
antibodies. The presence of brown cytoplasmic staining of cancer cells indicated positive immunoreactivity. To ensure the quality of immunostaining, incubation without the primary antibody was used as a negative control.

\section{Interpretation and scoring of immunohistochemistry}

All slides were blindly reviewed by two independent pathologists. Immunoreactivity was scored based on a combination of both the percentage and intensity of positively stained tumor cytoplasm to generate an $\mathrm{H}$-score. This was calculated using the following equation: $\mathrm{H}$-score $=\Sigma \mathrm{Pi}(\mathrm{i}+1)$, where $\mathrm{i}$ is the intensity of stained tumor cells $(0$ to $3+)$, and $\mathrm{Pi}$ is the percentage of stained tumor cells, varying from $0 \%$ to $100 \%$ [43].

\section{QuantiGene (branched DNA) assay to determine MCM10 transcript level}

Gene expression was analyzed using the QuantiGene Multiplex 2.0 assay systems (Affymetrix/Panomics Inc., Santa Clara, CA) per the manufacturer's instructions. In brief, custom probes specifically targeting the MCM10 transcript were designed by Affymetrix (Santa Clara, USA). Oligonucleotides of probe set were mixed with the lysed paraffin sections, and the mixture was added to an assay well in a 96-well plate coated with capture probe oligonucleotide. Target RNA was captured during an overnight incubation at $55^{\circ} \mathrm{C}$. Unbound materials was removed by three-run washes with $300 \mu$ l of wash buffer followed by subsequent hybridization of DNA amplifier molecules, and followed by three washes after incubation every time. After the final wash, the dioxetane alkaline phosphatase substrate Lumiphos Plus (Lumingen Inc., Southfield, MI, USA) was added to the reaction wells. After a short incubation, luminescent signal was detected using a Luminex 100 microplate luminometer (Luminex, TX, USA). The detected readout of MCM10 mRNA abundance was further normalized through the expression level of reference POLR2A transcript.

\section{Cell culture}

Four UC cell lines including RT4, T24, TCCSUP, and J82 were obtained from ATCC (Manassas, VA 20108, USA). TSGH8301, BFTC-905, and BFTC-909 were purchased from Food Industry Research and Development Institute (Hsinchu, Taiwan). An UTUC cell, RTCC1, was obtained from Professor Lien-Chai Chiang at Kaohsiung Medical University [44]. These cells were grown based on suggested medium and conditions.

\section{Quantification of MCM10 transcript}

Real-time RT-PCR was performed using an ABI StepOnePlus ${ }^{\mathrm{TM}}$ System to measure MCM10 mRNA abundance using the protocol as previously mentioned [45,
46]. RNeasy Mini kit (Qiagen, Valencia, CA) was used to extract total RNAs from human UC cell lines and stable clones of T24 and J82 cells with lentiviral vectors bearing either shMCM10 or shLacZ. RNAs were further reversetranscribed using SuperScript ${ }^{\mathrm{TM}}$ III First-Strand Synthesis System (Invitrogen, Carlsbad, CA) per the manufacturers' instructions. Real-time PCR assay to quantify the expression level of MCM10 transcript was performed using pre-designed TaqMan assay reagents (MCM10 Hs00218560_m1, and POLR2A Hs01108291_m1 from Applied Biosystems, Foster City, CA). The obtained data were normalized by the expression of $P O L R 2 A$ housekeeping transcript. After normalization to $P O L R 2 A$, the relative expression fold of $M C M$ transcript was then given by $2^{-\Delta \Delta \mathrm{Cp}}$, where $\Delta \Delta \mathrm{CT}=\Delta \mathrm{CT}$ (UC cells) $-\Delta \mathrm{CT}$ (calibrator), $\triangle \mathrm{CT}$ represented the $\mathrm{CT}$ of $M C M 10$ subtracted from the $\mathrm{CT}$ of $P O L R 2 A$, and the calibrator was RT4 cell. Only samples with $\mathrm{CT}$ value $<32$ for $P O L R 2 A$ were considered to have acceptable RNA quality and included in the analyses.

\section{Western blot assays}

The western blotting assay was performed based on that of our previous publications $[45,46]$ to evaluate the endogenous MCM10 expression and the efficiency of MCM10 knockdown in J82 and TCCSUP cell lines. Cell lysates containing $25 \mu \mathrm{g}$ protein were separated by $4-12 \%$ gradient NuPAGE gel (Invitrogen, Carlsbad, $\mathrm{CA}$ ), transferred onto PVDF membranes (Amersham, Biosciences, Buckinghamshire, UK). After blocking with $5 \%$ skimmed milk in TBST buffer at room temperature for $1 \mathrm{~h}$, the membranes were then probed with antibodies at $4{ }^{\circ} \mathrm{C}$ overnight against MCM10 (1:1000, H-41, Santa Cruz), and GAPDH as a loading control (6C5, 1:10,000, Millipore, Beverly, MA). After incubation with the secondary antibody at room temperature for $1.5 \mathrm{~h}$, proteins were visualized by the chemiluminescence system (Amersham Biosciences).

\section{RNA interference}

To establish stably silenced clones of MCM10amplified J82 and TCCSUP cell lines with the short-hairpin RNAs against MCM10 expression (shMCM10), the lentiviral vectors were obtained from Taiwan National RNAi Core Facility, including pLKO.1-shLacZ (TRCN0000072223: 5'-TGTTCGCATTAT CCGAACCAT-3') and pLKO.1shMCM10 (TRCN0000245425: 5'-TCATCCTCAGAAGG TCTTAAT-3'; TRCN0000245426: 5'-GACGGCGACGG TGAATCTTAT-3'). Viruses were produced by transfecting HEK293 cells with the above three vectors using Lipofectamine 2000 as previously described [45, 47]. For viral infection, $3 \times 10^{6} \mathrm{~J} 82$ or TCCSUP cells were incubated with $8 \mathrm{ml}$ lentivirus in the presence of polybrene, followed by puromycin selection for stable clones of lentivirustransduced cells. 


\section{Bromodeoxyuridine (BrdU) assay to assess cell proliferation}

Cell proliferation was assessed using an enzymelinked immunosorbent assay-based and colorimetric BrdU assay (Roche Diagnostics) as previously described [48, 49]. MCM10-knockdown or shLacZ control J82 and TCCSUP cells were plated into a 96-well plate at density of 3000 cells per well, and cell proliferation was evaluated at 24, 48, and $72 \mathrm{~h}$. After incubation with BrdU for 3 hours at $37^{\circ} \mathrm{C}$ under $5 \% \mathrm{CO} 2$, the labeling medium was removed, followed by fixation and final incubation with anti-BrdU-POD solution. The absorbance of the samples was measured using an ELISA reader (Promega) at $450 \mathrm{~nm}$, with the absorbance at $690 \mathrm{~nm}$ as reference.

\section{Statistical analysis}

Statistical analyses were performed using SPSS V.14.0 software (SPSS Inc. Chicago, IL, USA). The median $\mathrm{H}$-score of immunohistochemistry for MCM2 and MCM10 was used as the cutoff to dichotomize the study cohorts into high and low expression groups. Pearson's $x^{2}$ test was used to compare MCM2 and MCM10 expression and various clinicopathological features. The end points analyzed were disease-specific survival (DSS) and metastasis-free survival (MeFS). DSS and MeFS were calculated from the starting date of curative surgery to the date of an event development. Univariate and multivariate analyses were performed using the Kaplan-Meier method with the log-rank test and the Cox proportional hazards model. Student's t-test was used to analyze quantitative RT-PCR and functional assays for cell line samples. Statistical significance was set at $\mathrm{P}<0.05$.

\section{CONFLICTS OF INTEREST}

The authors declare no competing financial interest.

\section{GRANT SUPPORT}

This study was supported by Kaohsiung Medical University "Aim for the Top Universities" (KMUTP104E31, KMU-TP105G00, KMU-TP105G01, KMUTP105G02), the health and welfare surcharge of tobacco products, Ministry of Health and Welfare (MOHW105TDU-B-212-134007), Ministry of Science and Technology (MOST103-2314-B-037-067-MY3), and Kaohsiung Medical University Hospital (KMUH101-1R47, KMUH102-2R42), and the Biobank at Chi Mei Medical Center.

\section{REFERENCES}

1. Keeley FX, Jr., Bibbo M, Bagley DH. Ureteroscopic treatment and surveillance of upper urinary tract transitional cell carcinoma. The Journal of urology. 1997; 157:1560-1565.

2. Chen SH, Wu WJ, Tu HP, Li WM, Huang CN, Li CC, Lin $\mathrm{HH}, \mathrm{Ke} \mathrm{HL}$. Glutathione S-transferase expression in upper urinary tract urothelial carcinomas: a Taiwan study. Asian Pacific journal of cancer prevention : APJCP. 2013; 14:6475-6479.

3. Cancer Genome Atlas Research N. Comprehensive molecular characterization of urothelial bladder carcinoma. Nature. 2014; 507:315-322.

4. Ferreira-Teixeira M, Parada B, Rodrigues-Santos P, Alves V, Ramalho JS, Caramelo F, Sousa V, Reis F, Gomes $\mathrm{CM}$. Functional and molecular characterization of cancer stem-like cells in bladder cancer: a potential signature for muscle-invasive tumors. Oncotarget. 2015; 6:36185-36201. doi: 10.18632/oncotarget.5517.

5. Kawahara T, Shareef HK, Aljarah AK, Ide H, Li Y, Kashiwagi E, Netto GJ, Zheng Y, Miyamoto H. ELK1 is up-regulated by androgen in bladder cancer cells and promotes tumor progression. Oncotarget. 2015; 6:2986029876. doi: 10.18632/oncotarget.5007.

6. Chehab M, Caza T, Skotnicki K, Landas S, Bratslavsky G, Mollapour M, Bourboulia D. Targeting Hsp90 in urothelial carcinoma. Oncotarget. 2015; 6:8454-8473. doi: 10.18632/ oncotarget.3502.

7. Yeh CM, Chen PC, Hsieh HY, Jou YC, Lin CT, Tsai MH, Huang WY, Wang YT, Lin RI, Chen SS, Tung CL, Wu SF, Chang DC, Shen CH, Hsu CD, Chan MW. Methylomics analysis identifies ZNF671 as an epigenetically repressed novel tumor suppressor and a potential non-invasive biomarker for the detection of urothelial carcinoma. Oncotarget. 2015; 6:29555-29572. doi: 10.18632/ oncotarget. 4986 .

8. Witjes JA, Compérat E, Cowan NC, De Santis M, Gakis G, Lebret T, Ribal MJ, Van der Heijden AG, Sherif A; European Association of Urology. EAU guidelines on muscle-invasive and metastatic bladder cancer: summary of the 2013 guidelines. European urology 2014; 65:778-92.

9. Roupret M, Babjuk M, Comperat E, Zigeuner R, Sylvester RJ, Burger M, Cowan NC, Böhle A, Van Rhijn BW, Kaasinen E, Palou J, Shariat SF. European Association of Urology Guidelines on Upper Urinary Tract Urothelial Cell Carcinoma: 2015 Update. European urology. 2015; 68:868-79.

10. Hanahan D, Weinberg RA. Hallmarks of cancer: the next generation. Cell. 2011; 144:646-674.

11. Mitra A, Mishra L, Li S. EMT, CTCs and CSCs in tumor relapse and drug-resistance. Oncotarget. 2015; 6:1069710711. doi: 10.18632/oncotarget.4037.

12. Leonardi E, Girlando S, Serio G, Mauri FA, Perrone G, Scampini S, Dalla Palma P, Barbareschi M. PCNA and Ki67 expression in breast carcinoma: correlations with clinical and biological variables. Journal of clinical pathology 1992; 45:416-419. 
13. Roels S, Tilmant K, Ducatelle R. PCNA and Ki67 proliferation markers as criteria for prediction of clinical behaviour of melanocytic tumours in cats and dogs. Journal of comparative pathology 1999; 121:13-24.

14. Aparicio OM, Weinstein DM, Bell SP. Components and dynamics of DNA replication complexes in S. cerevisiae: redistribution of MCM proteins and $\mathrm{Cdc} 45 \mathrm{p}$ during $\mathrm{S}$ phase. Cell.1997; 91:59-69.

15. Chong JP, Mahbubani HM, Khoo CY, Blow JJ. Purification of an MCM-containing complex as a component of the DNA replication licensing system. Nature. 1995; 375:418-21.

16. Padmanabhan V, Callas P, Philips G, Trainer TD, Beatty BG. DNA replication regulation protein $\mathrm{Mcm} 7$ as a marker of proliferation in prostate cancer. Journal of clinical pathology. 2004; 57:1057-1062.

17. Ramnath N, Hernandez FJ, Tan DF, Huberman JA, Natarajan N, Beck AF, Hyland A, Todorov IT, Brooks JS, Bepler G. MCM2 is an independent predictor of survival in patients with non-small-cell lung cancer. Journal of clinical oncology. 2001; 19:4259-4266.

18. Guillou E, Ibarra A, Coulon V, Casado-Vela J, Rico D, Casal I, Schwob E, Losada A, Méndez J. Cohesin organizes chromatin loops at DNA replication factories. Genes \& development 2010; 24:2812-2822.

19. Zou L, Stillman B. Assembly of a complex containing $\mathrm{Cdc} 45 \mathrm{p}$, replication protein $\mathrm{A}$, and $\mathrm{Mcm} 2 \mathrm{p}$ at replication origins controlled by S-phase cyclin-dependent kinases and Cdc7p-Dbf4p kinase. Molecular and cellular biology. 2000; 20:3086-3096.

20. Gambus A, Jones RC, Sanchez-Diaz A, Kanemaki M, van Deursen F, Edmondson RD, Labib K. GINS maintains association of $\mathrm{Cdc} 45$ with $\mathrm{MCM}$ in replisome progression complexes at eukaryotic DNA replication forks. Nature cell biology. 2006; 8:358-366.

21. Williams GH, Romanowski P, Morris L, Madine M, Mills AD, Stoeber K, Marr J, Laskey RA, Coleman N. Improved cervical smear assessment using antibodies against proteins that regulate DNA replication. Proceedings of the National Academy of Sciences of the United States of America 1998; 95:14932-7.

22. Obermann EC, Eward KL, Dogan A, Paul EA, Loddo M, Munson P, Williams GH, Stoeber K. DNA replication licensing in peripheral B-cell lymphoma. The Journal of pathology. 2005; 205:318-328.

23. Jin Y, Xiong A, Zhang Z, Li S, Huang H, Yu TT, Cao X, Cheng SY. MicroRNA-31 suppresses medulloblastoma cell growth by inhibiting DNA replication through minichromosome maintenance 2. Oncotarget. 2014; 5:48214833. doi: 10.18632/oncotarget.2043.

24. Meng MV, Grossfeld GD, Williams GH, Dilworth S, Stoeber K, Mulley TW, Weinberg V, Carroll PR, Tlsty TD. Minichromosome maintenance protein 2 expression in prostate: characterization and association with outcome after therapy for cancer. Clinical cancer research. 2001; 7:2712-2718.

25. Tan DF, Huberman JA, Hyland A, Loewen GM, Brooks JS, Beck AF, Todorov IT, Bepler G. MCM2-a promising marker for premalignant lesions of the lung: a cohort study. BMC cancer. 2001; 1:6.

26. Abe S, Yamamoto K, Kurata M, Abe-Suzuki S, Horii R, Akiyama F, Kitagawa M. Targeting MCM2 function as a novel strategy for the treatment of highly malignant breast tumors. Oncotarget 2015; 6:34892-34909. doi: 10.18632/ oncotarget.5408.

27. Homesley L, Lei M, Kawasaki Y, Sawyer S, Christensen T, Tye BK. Mcm10 and the MCM2-7 complex interact to initiate DNA synthesis and to release replication factors from origins. Genes \& development. 2000; 14:913-926.

28. Lee JK, Seo YS, Hurwitz J. The Cdc23 (Mcm10) protein is required for the phosphorylation of minichromosome maintenance complex by the Dfp1-Hsk1 kinase. Proceedings of the National Academy of Sciences of the United States of America. 2003; 100:2334-2339.

29. Kliszczak M, Sedlackova H, Pitchai GP, Streicher WW, Krejci L, Hickson ID. Interaction of RECQ4 and MCM10 is important for efficient DNA replication origin firing in human cells. Oncotarget. 2015; 6:40464-40479. doi: 10.18632/oncotarget.6342.

30. Wohlschlegel JA, Dhar SK, Prokhorova TA, Dutta A, Walter JC. Xenopus Mcm10 binds to origins of DNA replication after Mcm2-7 and stimulates origin binding of Cdc45. Molecular cell. 2002; 9:233-240.

31. Tanaka S, Diffley JF. Interdependent nuclear accumulation of budding yeast Cdt1 and Mcm2-7 during G1 phase. Nature cell biology. 2002; 4:198-207.

32. Watase G, Takisawa H, Kanemaki MT. Mcm10 plays a role in functioning of the eukaryotic replicative DNA helicase, Cdc45-Mcm-GINS. Current biology : CB 2012; 22:343-349.

33. Jones RM, Petermann E. Replication fork dynamics and the DNA damage response. The Biochemical journal. 2012; 443:13-26.

34. Lei M. The MCM complex: its role in DNA replication and implications for cancer therapy. Current cancer drug targets. 2005; 5:365-380.

35. Kwon HJ, Hong YK, Park C, Choi YH, Yun HJ, Lee EW, Kim BW. Widdrol induces cell cycle arrest, associated with MCM down-regulation, in human colon adenocarcinoma cells. Cancer letters. 2010; 290:96-103.

36. Shreeram S, Sparks A, Lane DP, Blow JJ. Cell type-specific responses of human cells to inhibition of replication licensing. Oncogene. 2002; 21:6624-6632.

37. Going JJ, Keith WN, Neilson L, Stoeber K, Stuart RC, Williams GH. Aberrant expression of minichromosome maintenance proteins 2 and 5, and Ki-67 in dysplastic squamous oesophageal epithelium and Barrett's mucosa. Gut. 2002; 50:373-377. 
38. Lee YY, Wu WJ, Huang CN, Li CC, Li WM, Yeh BW, Liang PI, Wu TF, Li CF. CSF2 Overexpression Is Associated with STAT5 Phosphorylation and Poor Prognosis in Patients with Urothelial Carcinoma. Journal of Cancer. 2016; 7:711-721.

39. Li CF, Wu WJ, Wu WR, Liao YJ, Chen LR, Huang CN, Li CC, Li WM, Huang HY, Chen YL, Liang SS, Chow NH, Shiue YL. The cAMP responsive element binding protein 1 transactivates epithelial membrane protein 2 , a potential tumor suppressor in the urinary bladder urothelial carcinoma. Oncotarget. 2015; 6:9220-9239. doi: 10.18632/ oncotarget.3312.

40. Wang YH, Wu WJ, Wang WJ, Huang HY, Li WM, Yeh BW, Wu TF, Shiue YL, Sheu JJ, Wang JM, Li CF. CEBPD amplification and overexpression in urothelial carcinoma: a driver of tumor metastasis indicating adverse prognosis. Oncotarget. 2015; 6:31069-31084. doi: 10.18632/ oncotarget.5209.

41. Ma LJ, Wu WJ, Wang YH, Wu TF, Liang PI, Chang IW, He HL, Li CF. SPOCK1 Overexpression Confers a Poor Prognosis in Urothelial Carcinoma. Journal of Cancer. 2016; 7:467-476.

42. Li WM, Wei YC, Huang CN, Ke HL, Li CC, Yeh HC, Chang LL, Huang CH, Li CF, Wu WJ. Matrix metalloproteinase-11 as a marker of metastasis and predictor of poor survival in urothelial carcinomas. Journal of surgical oncology. 2016; 113:700-707.

43. McCarty KS, Jr., Szabo E, Flowers JL, Cox EB, Leight GS, Miller L, Konrath J, Soper JT, Budwit DA, Creasman WT, Seigler HF, McCarty KS. Use of a monoclonal anti-estrogen receptor antibody in the immunohistochemical evaluation of human tumors. Cancer research. 1986; 46:4244s-4248s.

44. Chiang LC, Chiang W, Chang LL, Wu WJ, Huang CH. Characterization of a new human transitional cell carcinoma cell line from the renal pelvis, RTCC-1/KMC. Kaohsiung J Med Sci. 1996; 12:448-452.

45. Li CF, Chen LT, Lan J, Chou FF, Lin CY, Chen YY, Chen TJ, Li SH, Yu SC, Fang FM, Tai HC, Huang HY. AMACR amplification and overexpression in primary imatinib-naïve gastrointestinal stromal tumors: a driver of cell proliferation indicating adverse prognosis. Oncotarget. 2014; 5:1158811603. doi: 10.18632/oncotarget.2597.

46. Li CF, Fang FM, Kung HJ, Chen LT, Wang JW, Tsai JW, Yu SC, Wang YH, Li SH, Huang HY. Downregulated MTAP expression in myxofibrosarcoma: A characterization of inactivating mechanisms, tumor suppressive function, and therapeutic relevance. Oncotarget. 2014; 5:11428-11441. doi: 10.18632/oncotarget.2552.

47. Chi JY, Hsiao YW, Li CF, Lo YC, Lin ZY, Hong JY, Liu YM, Han X, Wang SM, Chen BK, Tsai KK, Wang JM. Targeting chemotherapy-induced PTX3 in tumor stroma to prevent the progression of drug-resistant cancers. Oncotarget. 2015; 6:23987-24001. doi: 10.18632/oncotarget.4364.

48. Benedetti E, Antonosante A, d'Angelo M, Cristiano L, Galzio R, Destouches D, Florio TM, Dhez AC, Astarita C, Cinque B, Fidoamore A, Rosati F, Cifone MG, Ippoliti R, Giordano A, Courty J, Cimini A. Nucleolin antagonist triggers autophagic cell death in human glioblastoma primarycells and decreased in vivo tumor growth inorthotopic brain tumor model. Oncotarget. 2015; 6:4209142104. doi: 10.18632/oncotarget.5990.

49. Ching RH, Lau EY, Ling PM, Lee JM, Ma MK, Cheng BY, Lo RC, Ng IO, Lee TK. Phosphorylation of nucleophosmin at threonine 234/237 is associated with HCCmetastasis. Oncotarget. 2015; 6:43483-43495. doi: 10.18632/ oncotarget.5820. 